\title{
Free and Open Borders and Their Role in Security Matters
}

\author{
Blerta Derhemi (Bitri) \\ PHD in process, Ministry of Foreign Affairs, Tiranë, Albania \\ blertaderhemi@yahoo.com
}

\section{Doi:10.5901/mjss.2013.v4n10p268}

\begin{abstract}
Migration today is one of humanity's most dominant phenomenons. Albania is one of the countries with more developed immigration, about $25 \%$ of it's the population are illegal emigrants. Illegal migration is a potential risk for security. Migration policy, except being used for development, should focus more on the negative effects of migration in the security field. Trends to support tourism or the economy, the motto for free movement of people and goods across borders, sometimes divert attention from security issues. Misbalances of the two components of the motto "free and open borders", but "safe and controlled" directly affects the security sector. This paper attempts to bring an innovative analysis of migration policy, not only as a factor of development, but especially its impact on security.
\end{abstract}

\section{Introduction}

Now days more than ever the focus on security issues has involved not only Albania but all countries of region, European Union countries and more over. Migratory flows from South of Africa to Europe last years were a risk even for Schengen zone, one of the best achievements of European Union. Those flows risked seriously the security aspects. International terrorism also has become as one of the decisive factor for the states' entrance policies for the foreigners. Particularly after 11 September 2001 in USA, many countries of Europe, firstly one by one and then with a common policy, started implementation of very strict control for foreigner citizens.

Often security issues are used as alibi to limit or suspend the emigrants' rights. Higher scale of crime activity and terrorism results on a higher dose of suspicion for emigrants'. In this situation the key of success can be finding at the balance between security issues and the respect for the migration rights.

Even though, there are a lot of studies about migration there are not so many papers about the impact of migration of the security field. Base subject of this paper will refers to the migration policy and their role in security field. Secondly it will be focused to describe the role of Albania in its own security and in global security.

\section{European Union Migration Policy}

Migration Law of European Union is relatively a new one, but it is going to be enriched quickly as a response to development of migration issues in Europe. Currently there is an entirety of migration norms that stay as a base for European Union (EU) migration policy. Those Migration Policies aimed to strength EU, as a zone of freedom, security and justice. Without analyzing every member country elements of migration policies, a common policy of EU aimed to manage effectively the migration has been and it is still now highlighted by EU institutions. EU migrations policy on the light of its role in security is three dimensional.

1- Matters of foreigners' entrance and residence

2- Fight against the illegal migration

3- Removal and expulsion of foreigners

\subsection{Matters of foreigners' entrance and residence}

Regarding to the entrance policy the member countries of EU, almost have harmonized their own policies to a common policy expressed in Schengen Code, special directives, regulations etc. that are integral parts of Acquis Communaitare.

First of all, this policy is based on the Schengen Zone fundamental entrance condition, on categorizing countries that can enter with visa or without visa in that zone. Also it is made a unification of short term residence, not more than 90 days for 180 days how it known on the visa policy vocabulary. 
Secondly this policy is completed by other general conditions that a foreigner has to fulfill on the moment of entrance on external Schengen border. Also it is depended on the competences of border authorities to control about the fulfillment of conditions and to decide case by case.

If refer to the EU visa policy, its core is made by the probability of third countries to "export insecurity" for member countries.

\subsection{Fight against the illegal migration}

Fight against the illegal migration is a key element of migration policy of EU, since it is directly connected with the main goal of community; gradual creation of a common area of freedom, security and justice.

Fight against the illegal migration can be treated like the entire measures to control and prevent the illegal entrance of external borders of Schengen, to control the illegal residence on Schengen area, fight against the traffic of human beings etc. Control of external Schengen border is responsibility of every member country but the policy, strategy, critters, standards and procedures, systems of informative technologies are unified for all Schengen area. Also on interest of management and control of borders EU has built up a special structure such as FRONTEX. Regarding the illegal stay in Schengen territory, EU has unified the measures policy not only for the illegal residents but for persons who favorite them through employment, housing, transporting etc.

\subsection{Removal and expulsion of foreigners}

Policy of removal and expulsion of foreigners, otherwise known as return and readmission policy is a very important part of migration policy that is strongly connected with the fight against the illegal migration. Return policy of EU is based in to many important documents like Convention for the Implementation of Schengen Agreement and a couple of directives through which EU unify the return policy third countries' citizens who stay illegally in the Schengen area. On the light of security, return policy has in its core the subjects of return, motives of return and the detention measures for entrance of those subjects in EU. Because of its importance readmission policy is a main condition of visa liberalization or visa facilitate process for third countries.

\section{Migration Policy of Albania}

Migration policy of Albania is made by two parts, immigration policy and emigration policy. These policies are drafted and approved in accordance with migration policy and migration norms of European Union, aiming to minimize the costs of illegal migration and maximize the benefits of legal migration. Albanian migration policy has passed a long way to be improved time after time under the indication of migration fluxes of Albanians mainly after 1990. But it has been evaluated in accordance with EU migration policy evaluation and standards asked by EU for the Albania integration process.

In interest of this paper are the questions as below;

Does this policy have a positive impact on security field or not? Is our emigration policy a guaranteed one for our neighbors' countries, region and more? Does it prevent the "import of insecurity" from other third countries potentially to enter illegally in EU?

Object of this analyze will be elements or components of migration policy that indicate security field. This analyze will help understanding of our migration policy in comparison with security,

Albanian migration policy in its security point of view is three dimensional. It is compounded by;

a) Issues of Albanian citizens movement abroad

b) Entrance and residence of foreigners in Albania

c) Fight against illegal migration

Except the border crossing facilitate policy, a particular importance is given to borders security. Its goal is preventing the illegal entrance and exit from Republic of Albania. Albanian legislation from one side aims to use immigration as development opportunity but from the other side it aims to be a guaranty for public order and the national security.

Juridical norms, critters, procedures, documentations for entrance and stay of foreigners in the Republic of Albania, Administrative measures for who violate this legislation are compiling not only to respect all the convents and international acts that are signed by Albanian Government but to secure national security and public order. 
Policy of issuing visa and residence permits for foreigners' respects and guarantee the human rights but at the same time, procedures of verification and the cooperation of some specialized structures in the security sector aims to prevent importation of security risks including Albania and neighbor countries of the region.

The Strategy for Integrated Management of Borders has emphasized "Main strategically goal of Albanian Government is development of a border security system that will integrate all governmental agencies responsible for border control". Also Albanian Penal Code provides administrative and penal measures for all persons who cross borders illegally or help the others to enter or exit albanian borders illegally. These are repressive parts of migration policy needed last decades since illegal emigration from Albania to European Union had been a concern for those countries.

\section{Migration and its impact in Security Sector}

Migration is exit of persons from origin countries with the purpose for a long stay in to destination country, to work, study or family reunion etc. Illegal migration has an emphasized negative impact on security sector because persons who enter, stay or transit from their origin country to destination are not controlled and monitored.

History tells that terrorists who have risks highly not only a country but risks the entire world most of the times are illegal migrants. But not only illegal migrants are risks for security, legal migrant sometimes are as well. Setting mechanism of terrorist or other criminal groups in developed countries through the legal scheme of migration with the motives like employment or politic asylum is today a real concern for migration and security services.

The impact of illegal immigration can be for the origin countries, transit and destination countries. In the first view it looks like exit of criminal elements from the origin countries save them from the presence and criminal activity. In fact illegal migration has a direct impact in security of origin country.

Firstly migration of criminal elements in most of the cases has aims to escape the justice. Often their absence has a negative impact on the investigation and detection of criminal acts. Lack of justice sometimes is equally with lack of security in a country.

Secondly the illegal migration is developed through human beings contraband or human beings traffic. In both cases citizens pay a lot of money for an illegal migration, it means finance criminal groups and empowers one of the most important elements of criminal logistic, finance.

In the destination countries illegal migration has a high impact on security sector. Percentage of criminal acts of legal migrants is very low if it is compared with the percentage of criminal acts of illegal migrants.

Illegal migration has the same impact in transit countries. Transit migrants usually stay for a long time in those countries until they can go to destination country. During this time they can cause the same problems on security like in destination country.

\section{Conclusions}

1- Illegal migration is a phenomenon with a direct impact in security field. Migration today is widely extended in so many countries and has global features also his impact on security field has the same importance to many global issues.

2- Building up and strengthening of migration partnerships among countries means building up and guaranty for common security.

3- The key of success in the open borders and free movement world is the balance between security issues and respect of migration rights. That will bring a right migration management.

4- Harmonization of migration policies of origin and destination countries including transit ones, has its direct impact on creating an common unified policy that will build up gradually a free, secure and justice zone.

\section{References}

IOM (The International Organization for Migration) Albanian Migration Profile 2007

IOM (The International Organization for Migration) Albanian Migration Profile 2008

National Strategy for Integrated Management of Borders, Action Plan approved by the Decision of the Council of Ministers No.668, date 29.09.2007

Low for Foreigners, No. 108/2013, date 28.03.2013

Low No.9861, date 24.01.2008 "Control and Surveillance of State Borders"

COM (2002) 564 final. Communication from the commission to the council and the European Parliament on a community return policy and illegal; residents. 